\title{
KESAN INTERAKSI PENDEKATAN PEMBELAJARAN DAN FAKTOR JANTINA PELAJAR KE ATAS PENCAPAIAN SUBJEK KIMIA MELALUI KAEDAH PBL via FACEBOOK
}

\author{
${ }^{1}$ Mohd Shahir Mohamed Sunar, ${ }^{2}$ Ahmad Jelani Shaari \\ ${ }^{1}$ Kolej MARA Kuala Nerang, \\ 06300 Kuala Nerang Kedah, Malaysia \\ ${ }^{2}$ Fakulti Pendidikan dan Bahasa Moden, \\ Universiti Utara Malaysia, \\ 06010, Sintok Kedah, Malaysia.
}

Received : 07 Oktober 2017; Accepted : 02 Febuari 2018; Published : 26 Jun 2018

\begin{abstract}
Abstrak
Pengaruh media sosial seperti Facebook dalam pelbagai bidang termasuk bidang pendidikan tidak dapat dinafikan lagi. Objektif utama kajian adalah mengkaji kesan interaksi pendekatan pembelajaran dan faktor jantina pelajar ke atas pencapaian subjek kimia secara kaedah pembelajaran berasaskan masalah (problem based learning) melalui Facebook. Sampel kajian terdiri daripada 120 orang pelajar Kolej MARA yang telah dipilih secara rawak untuk menjalani rawatan $P B L$ via Facebook selama sembilan minggu. Kajian kuantitatif ini menggunakan reka bentuk eksperimen secara faktorial $2 \times 2$. Kesan utama yang dikaji adalah pendekatan pembelajaran (permukaan dan mendalam) dan faktor jantina (lelaki dan perempuan) serta interaksi kedua-duanya ke atas pencapaian dalam peperiksaan akhir subjek kimia. Hasil analisis deskriptif menunjukkan berlakunya peralihan pendekatan pembelajaran pelajar daripada pendekatan permukaan kepada pendekatan mendalam selepas menjalani rawatan PBL via Facebook. Hasil ujian Anova Dua-Hala pula menunjukkan bahawa kesan utama pendekatan pembelajaran terhadap pemboleh ubah bersandar pencapaian pelajar adalah signifikan merentasi jantina pelajar. Walau bagaimanapun, kesan utama jantina dan kesan interaksi antara kedua-dua pemboleh ubah bebas terhadap pencapaian pelajar adalah tidak signifikan. Hasil kajian ini penting kerana Kaedah PBL via Facebook didapati berupaya mendorong peralihan amalan pendekatan pembelajaran pelajar daripada pendekatan pembelajaran permukaan kepada pendekatan pembelajaran mendalam. Pendekatan pembelajaran mendalam seterusnya membolehkan pelajar untuk memperoleh pencapaian akademik yang lebih baik.
\end{abstract}

Kata kunci pendekatan pembelajaran mendalam, pendekatan pembelajaran permukaan, Facebook, kaedah pembelajaran berasaskan masalah.

\begin{abstract}
The influence of social media such as Facebook in various fields including education field cannot be denied. The main objective of this study is to
\end{abstract}


examine the effects of interaction of students' learning approach and their gender to the achievement of chemistry subject using problem-based learning (PBL) methods via Facebook. The sample consisted of 120 students from Kolej MARA who were randomly selected to undergo PBL treatment via Facebook for nine weeks. This quantitative study used experimental design with $2 \times 2$ factorial. The key outcomes studied were the interaction of both students' learning approaches (surface and in-depth) and gender (male and female) on the achievement of chemistry final examination. Descriptive analysis showed a shift from surface learning approach to in-depth learning approach after PBL treatment via Facebook. The results of two-way ANOVA test showed that the main effect of students' learning approach on the student achievement is significant across gender. However, the main effect of gender and the impact of the interaction between the two independent variables on student achievement is not significant. The results of this study are important because PBL via Facebook has been found to have the ability to encourage the transition from surface learning approach to in-depth learning approach among students. The in-depth learning approach then enables students to obtain better academic achievement.

Keywords in-depth learning approach, surface learning approach, Facebook, problem-based learning methods.

\section{PENDAHULUAN}

Perkembangan pesat serta penggunaan meluas Teknologi Web 2.0 seperti laman blog, Flickr, YouTube, MySpace, Facebook, Twitter, Whatsapp dan sebagainya telah menyaksikan transformasi berlaku dalam pelbagai aspek kehidupan merangkumi bidang politik, ekonomi, pendidikan, sosial, cara perolehan sumber maklumat dan juga budaya kerja. Menurut Boyd dan Ellison (2008), media sosial khususnya laman rangkaian sosial (social networking sites) boleh didefinisikan sebagai kemudahan laman web yang membolehkan (i) individu membina profil diri bagi tatapan umum atau separa umum (keterpilihan) dalam sistem yang mempunyai batasan tertentu, (ii) mengutarakan atau memaparkan senarai pengguna lain yang mempunyai hubungan persahabatan secara maya dengan individu tersebut dan (iii) melihat atau merentasi senarai rakan-rakan yang diwujudkan oleh seseorang individu lain dalam satu lingkungan sistem yang sama untuk tujuan penambahan sebagai rakan. Kebanyakan penggunaan Facebook adalah bertujuan untuk menghantar mesej, memuat naik dan turun muzik atau video, berkongsi maklumat, mengemas kini profil diri, menghantar gambar, mengirim e-mel dan pelbagai lagi aktiviti-aktiviti lain (Rainie, 2009). Dalam masa yang begitu singkat, Facebook telah muncul sebagai media sosial yang paling popular di dunia, mencecah sehingga 500 juta ahli yang aktif pada Julai 2010 iaitu hanya enam tahun selepas penubuhannya (Paul, 2010). Angka tersebut didapati terus meningkat dengan begitu cepat dan pada tanggal 4 Oktober 2012, pengguna Facebook telah mencapai angka 1 billion (Facebook.com, 2012). 
Sehingga Mac 2017 sahaja, terdapat lebih daripada 1.94 bilion pengguna aktif yang menggunakan Facebook (Facebook.com, 2017).

Perkembangan aplikasi media sosial juga didapati begitu popular dalam kalangan rakyat Malaysia terutamanya golongan muda. Hasil kajian Syed Shah Alam, Yeow dan Loo (2011), secara purata didapati golongan remaja di Malaysia telah meluangkan masa selama 5 minit hingga 3 jam sehari bagi tujuan mengemas kini status diri, membaca status rakan, memberi komen, menghantar mesej dan lain-lain. Menurut beliau lagi, Facebook merupakan media sosial yang paling popular dalam kalangan pelajar Malaysia diikuti dengan media sosial yang lain. Sehingga Mac 2015, jumlah pengguna media sosial Facebook di Malaysia telah mencecah sehingga 15 juta orang (Socialbakers.com, 2015). Hal ini bermakna hampir separuh rakyat Malaysia telah membuka atau memiliki akaun Facebook. Golongan remaja berusia di antara 18 hingga 24 tahun telah dikenal pasti sebagai kumpulan terbesar pengguna Facebook di Malaysia dengan pecahan sebanyak $34 \%$ dan diikuti golongan dewasa yang berumur di antara 25 hingga 34 tahun yang mewakili 28\% pengguna (Socialbakers.com, 2015).

Fenomena media sosial Facebook sebagai laman sosial yang paling popular dalam kalangan remaja, turut berlaku di Kolej MARA. Satu tinjauan awal telah dijalankan di Kolej MARA dengan menggunakan instrumen kajian Roblyer, McDaniel, Webb, Herman dan Witty (2010) untuk mengkaji persepsi awal pelajar terhadap aplikasi media sosial dalam pendidikan peringkat tinggi. Instrumen kajian ini yang terdiri daripada sembilan item telah diberikan secara rawak kepada seratus orang pelajar yang menuntut di Kolej MARA. Beberapa hasil tinjauan awal ditunjukkan dalam jadual berikut:

Jadual 1 Peratus Pemilikan Akaun Facebook dalam Kalangan Pelajar Kolej MARA

\begin{tabular}{ll}
\hline Pemilikan akaun Facebook $(\mathbf{n}=\mathbf{1 0 0})$ & Peratus $(\%)$ \\
\hline Memiliki akaun Facebook & 99 \\
Tidak memiliki akaun Facebook & 1 \\
\hline
\end{tabular}

Jadual 2 Peratus bilangan kali membuat semakan akaun Facebook dalam sehari

\begin{tabular}{lc}
\hline Bilangan kali membuat semakan dalam sehari (n=100) & Peratus (\%) \\
\hline Tidak memiliki akaun Facebook & 1 \\
Kurang sekali dalam sehari & 4 \\
1-5 kali dalam sehari & 27 \\
6-10 kali dalam sehari & 35 \\
11-15 kali dalam sehari & 22 \\
16-20 kali dalam sehari & 7 \\
Lebih daripada 20 kali dalam sehari & 4 \\
\hline
\end{tabular}


Jadual 3 Peratus persepsi pelajar berkenaan penggunaan Facebook dalam pendidikan

\begin{tabular}{lc}
\hline Persepsi pelajar $(\mathbf{n}=\mathbf{1 0 0})$ & Peratus (\%) \\
\hline Ia sangat memudahkan & 62 \\
$\begin{array}{l}\text { Saya menyambut baik peluang untuk berhubung dengan rakan- } \\
\text { rakan sekelas }\end{array}$ & 21 \\
Facebook adalah untuk tujuan peribadi (bersosial) & 9 \\
$\quad$ - bukan untuk pendidikan! & \\
Hak peribadi (privasi) saya akan diceroboh & 3 \\
Saya tidak kisah & 5 \\
\hline
\end{tabular}

Dapatan tinjauan awal ini jelas memberikan petunjuk positif bahawa media sosial sangat signifikan dalam kehidupan seharian pelajar masa kini bahkan majoriti pelajar didapati menyambut baik cadangan untuk mengintegrasikan media sosial dalam proses pembelajaran mereka. Kecenderungan dan kekerapan penggunaan Facebook dalam kalangan pelajar ini telah mencetuskan idea kepada para pendidik dan penyelidik untuk mengkaji kesesuaian dan keberkesanan penggunaan media sosial tersebut dalam konteks pendidikan. Namun, kajian empirikal berkenaan keberkesanan penggunaan media sosial dalam bidang pendidikan masih di peringkat awal dan belum berkembang sepenuhnya (Çevik, 2014; Sobaih, Moustafa \& Ghandforoush, 2016). Media sosial seperti Facebook boleh dipertimbangkan sebagai sebahagian media interaktif pendidikan kerana mempunyai ciri-ciri yang membolehkan interaksi berlaku, pertukaran pendapat dan maklum balas serta menepati ciri-ciri pembelajaran mengikut konteks pembelajaran sosial (Kabilan, Ahmad \& Zainol Abidin, 2010; Manca \& Ranieri, 2013; Sobaih et al., 2016).

Kesesuaian media sosial seperti Facebook untuk diintegrasikan dalam proses pengajaran dan pembelajaran adalah berdasarkan kepada dua teori pembelajaran yang terkemuka iaitu Teori Pembelajaran Sosial (Bandura, 1977) dan Teori Pembelajaran Sosiobudaya (Vygotsky, 1978). Teori Pembelajaran Sosial menyatakan bahawa individu atas inisiatifnya sendiri akan sentiasa terarah untuk memulakan dan seterusnya mengawal pembelajaran mereka untuk mencapai hasil pembelajaran yang diingini. Teori ini juga menekankan interaksi pembelajaran bersama rakan-rakan dengan melihat pembelajaran sebagai satu proses sosial di mana setiap individu akan berinteraksi dengan rakan sebaya, modelnya dan juga situasi di sekelilingnya. Manakala Teori Pembelajaran Sosiobudaya pula menyatakan bahawa proses pembelajaran perlu lebih memfokuskan kepada interaksi sosial, bahasa dan budaya. Teori ini memberikan penekanan kepada proses pembelajaran yang bukan hanya dilihat sebagai suatu proses yang melibatkan individu atau perseorangan sahaja namun ia merupakan suatu proses perkembangan individu dalam lingkungan persekitaran sosial (Hung, 2002). Beberapa kajian awal seperti Tess (2013) dan Çevik (2014) telah mencadangkan pelaksanaan pembelajaran berintegrasikan media sosial dengan kaedah pembelajaran yang bersifat aktif dan kontemporari seperti pembelajaran berasaskan masalah (problem based learning). Melalui kaedah ini, dijangkakan tahap pemikiran pelajar menjadi lebih kritis selain menggalakkan pembinaan pengetahuan yang lebih mendalam (Tess, 2013). 
Selain itu, kaedah tersebut juga dijangka berupaya memenuhi kepelbagaian latar belakang pendekatan pembelajaran yang diamalkan oleh pelajar (Aghili, Palaniappan, Kamali, Aghabozorgi \& Sardareh, 2014). Pendekatan pembelajaran merupakan satu konsep yang menerangkan bagaimana penerimaan atau persepsi seseorang pelajar terhadap subjek atau tugasan yang diberikan (Ramsden, 1992). Berdasarkan kajian Watkins (1982), terdapat dua jenis pendekatan pembelajaran iaitu pendekatan pembelajaran permukaan (surface) dan pendekatan pembelajaran mendalam (deep). Sekiranya seseorang pelajar itu mempunyai persepsi yang positif terhadap sesuatu subjek, mereka akan mengamalkan pendekatan pembelajaran mendalam, namun sebaliknya jika pelajar mempunyai persepsi yang negatif mereka didapati akan mengamalkan pendekatan pembelajaran permukaan (Ramsden, 1992). Pelajar akan memilih secara sedar sama ada untuk mengamalkan pendekatan mendalam atau permukaan dan implikasi pemilihan tersebut adalah penting dalam menentukan hasil akhir pencapaian pelajar selain daripada faktor kaedah pembelajaran yang digunakan (Biggs, Kember \& Leung, 2001). Hal ini kerana pendekatan pembelajaran merupakan satu konsep asas yang mempertimbangkan proses pembelajaran dan hasil kualiti pembelajaran (Duff, Boyle, Dunleavy \& Ferguson, 2004). Justeru, kajian secara kaedah eksperimen ini telah dijalankan dengan mengkaji keberkesanan kaedah pembelajaran berasaskan masalah $(P B L)$ melalui Facebook bagi subjek kimia selain turut mempertimbangkan latar belakang pendekatan pembelajaran yang diamalkan oleh setiap pelajar.

\section{SOROTAN LITERATUR}

Pembelajaran berasaskan masalah (problem-based learning) telah diperkenalkan oleh Howard S. Barrows dan pertama kali dilaksanakan di Universiti McMaster dalam bidang perubatan sekitar tahun 1960an (Barrows \& Tamblyn, 1980). Pada asalnya, idea pelaksanaan pembelajaran berasaskan masalah timbul setelah didapati kebanyakan pelajar bidang perubatan ketika itu gagal dalam mengaplikasikan pengetahuan mereka di persekitaran atau suasana klinikal sebenar, walaupun setelah mencapai keputusan yang cemerlang dalam peperiksaan akhir. Justeru, kaedah pembelajaran berasaskan masalah telah dibangunkan dalam usaha untuk menyediakan pelajar dengan suasana pembelajaran yang hampir sama seperti keadaan atau amalan klinikal sebenar. Suasana pembelajaran seperti ini berupaya menyediakan pelajar dengan kemahiran-kemahiran yang relevan dengan suasana sebenar selain menggalakkan pelajar mengamalkan pembelajaran secara lebih mendalam (Tan \& Mohammad Yusof Arshad, 2014). Bermula dengan hanya bidang perubatan, kini pembelajaran berasaskan masalah turut digunakan secara meluas dalam bidang-bidang yang lain dengan hampir semua universiti di seluruh dunia. Di negara-negara maju seperti Amerika Syarikat, pembelajaran berasaskan masalah bukan sekadar dipraktikkan di peringkat universiti sahaja, bahkan telah mula diperkenalkan di peringkat sekolah menengah seawal tahun 1990an (Barrows \& Kelson, 1993).

Kaedah pembelajaran berasaskan masalah juga didapati bukanlah sesuatu yang asing bagi kebanyakan pelajar di universiti awam mahu pun swasta di 
Malaysia. Namun begitu, kajian yang dilakukan oleh Tan dan Mohammad Yusof Arshad (2014) mendapati kaedah ini masih belum dilaksanakan secara meluas di kebanyakan universiti di Malaysia, walaupun kaedah ini telah lama diketahui umum. Selain itu, kebanyakan pelajar universiti awam didapati mula mengenali kaedah pembelajaran berasaskan masalah ini hanya selepas mereka melanjutkan pengajian di peringkat universiti (Tan \& Mohammad Yusof Arshad, 2014). Dengan lain perkataan, kaedah ini tidak didedahkan kepada pelajar ketika mereka berada di bangku sekolah menengah mahu pun sewaktu mengikuti program persediaan universiti seperti Sijil Tinggi Pelajaran Malaysia (STPM), matrikulasi atau A-Level (Hussain Othman \& Berhannudin M. Salleh, 2009; Tan \& Mohammad Yusof Arshad, 2014). Bahkan, sebahagian besar dalam kalangan pelajar serta guru di peringkat sekolah menengah Malaysia tidak pernah terfikir atau mengetahui tentang kaedah pembelajaran berasaskan masalah dan bagaimana pula cara pelaksanaannya (Faaizah \& Halimah, 2007). Hasil sorotan literatur yang dilakukan oleh penyelidik juga mendapati kurangnya kajian yang mengkaji keberkesanan kaedah pembelajaran berasaskan masalah sama ada di peringkat sekolah menengah mahu pun di peringkat pra-universiti. Keadaan ini didapati telah menyukarkan para pensyarah untuk melaksanakan kaedah tersebut di peringkat universiti disebabkan para pelajar langsung tidak memiliki latar belakang pembelajaran aktif (seperti pembelajaran berasaskan masalah) sebelum ini, lantaran mereka datang daripada sistem pembelajaran yang pasif, mengharapkan bahan daripada guru semata-mata (spoon$f e d$ ) dan sistem persekolahan yang terlalu berasaskan peperiksaan (Hussain Othman \& Berhannudin M. Salleh, 2009; Khairiyah Mohd Yusof, Syed Ahmad Helmi Syed Hassan \& Zaidatun Tasir, 2009; Tan \& Mohammad Yusof Arshad, 2014). Berdasarkan situasi tersebut, maka terdapat rasional atau asas yang kukuh untuk memperkenalkan kaedah pembelajaran berasaskan masalah sejak di bangku sekolah menengah atau pra universiti terutamanya. Keadaan ini membolehkan pelajar memiliki pengetahuan atau kebolehan asas dalam proses pembelajaran berasaskan masalah lebih awal dan seterusnya dapat mengelakkan mereka daripada berasa kekok dan gementar apabila diberikan tugasan pembelajaran berasaskan masalah di peringkat universiti kelak (Tan \& Mohammad Yusof Arshad, 2014).

Kini, selari dengan perkembangan pesat teknologi semasa, kaedah pembelajaran berasaskan masalah telah mengalami pelbagai perubahan. Sebagai contoh, perkembangan teknologi Web 2.0 telah membolehkan interaksi dan kolaborasi sesama pelajar menjadi begitu mudah terutamanya ketika proses perbincangan dalam mencari penyelesaian terhadap sesuatu permasalahan (Treepuech, 2011; Sobaih et al., 2016). Bahkan salah satu produk terpenting teknologi Web 2.0 iaitu media sosial (contohnya Facebook) didapati berpotensi dalam memudahkan lagi proses pembelajaran berasaskan masalah dilaksanakan (Wiboolyasarin, 2014). Seterusnya, beberapa kajian lanjutan yang dijalankan telah berjaya menghasilkan model pembelajaran yang menjadikan media sosial seperti Facebook sebagai alat (tool) pembelajaran. Sebagai contoh, Model Pembelajaran Teradun melalui Media Sosial secara Pembelajaran Berasaskan Masalah (Wiboolyasarin, 2014) yang melibatkan lapan peringkat pembelajaran. Peringkat tersebut adalah persediaan, mengenal pasti, analisis, proses penyelidikan, penghasilan, pengujian, rumusan dan 
penilaian. Menurut Manca dan Ranieri (2013), pelaksanaan kaedah pembelajaran yang berintegrasikan media sosial dengan kaedah pembelajaran yang bersifat aktif dan kontemporari seperti pembelajaran berasaskan masalah (problem based learning) dijangka berupaya meningkatkan keupayaan komunikasi pelajar, daya kreativiti, kebolehan untuk bekerjasama atau berkolaborasi dalam kumpulan dan pemikiran secara kritis dalam kalangan pelajar.

Selain itu, kaedah pembelajaran berasaskan masalah melalui media sosial juga dijangka berupaya untuk memenuhi kepelbagaian latar belakang pendekatan pembelajaran yang diamalkan oleh setiap pelajar (Wiboolyasarin, 2014). Berdasarkan Biggs, Kember dan Leung (2001), pendekatan pembelajaran berperanan penting dalam menentukan hasil akhir pencapaian pelajar dalam sesuatu pembelajaran. Hal ini disebabkan pendekatan pembelajaran merupakan satu konsep asas yang mempertimbangkan proses pembelajaran dan hasil kualiti pembelajaran pelajar (Duff, Boyle, Dunleavy \& Ferguson, 2004). Bagi pelajar yang memilih pendekatan pembelajaran permukaan, mereka akan melaksanakan sesuatu tugasan pembelajaran dengan meletakkan matlamat sekadar lulus atau hanya memperoleh gred yang minimum (Biggs \& Moore, 1993). Pembelajaran secara pendekatan permukaan menjadi sesuatu yang dilihat oleh pelajar sebagai mengimbangi antara tidak terlalu tekun berusaha dan tidak pula gagal dalam pembelajaran. Sebaliknya, bagi pendekatan mendalam, motif pembelajaran pelajar adalah minat secara dalaman (intrinsik) untuk memahami konsep dan makna dalam subjek tertentu dan seterusnya membina kompeten dalam subjek tersebut (Biggs, 1987). Menurut Newble dan Hejka (1991), pelajar yang mengamalkan pendekatan mendalam dimotivasikan oleh minat mereka terhadap subjek tersebut. Justeru, strategi yang digunakan adalah dengan memahami makna dan konsep menerusi pembacaan yang banyak dan menghubung kaitkan ilmu yang dipelajari dengan pengetahuan dan pengalaman sedia ada (Biggs, 1987) serta memahami corak dan prinsip-prinsip asas dalam sesuatu subjek itu (Entwistle, 1997).

\section{OBJEKTIF KAJIAN}

Secara umum, kajian ini dijalankan untuk mengenal pasti keberkesanan kaedah pembelajaran berasaskan masalah melalui media sosial Facebook bagi subjek kimia. Kajian ini juga telah mengambil kira latar belakang jantina dan pendekatan pembelajaran yang diamalkan pelajar. Kesan integrasi media sosial dalam pembelajaran subjek kimia kemudiannya akan dinilai menerusi pencapaian pelajar dalam ujian pos yang dilaksanakan di akhir semester pembelajaran. Objektif khusus kajian ini dijalankan adalah untuk:

1. Mengenal pasti pendekatan pembelajaran pelajar (permukaan dan mendalam) sebelum dan selepas menerima rawatan secara kaedah pembelajaran berasaskan masalah melalui media sosial Facebook bagi subjek kimia di Kolej MARA. 
2. Mengenal pasti kesan faktor jantina pelajar ke atas pencapaian subjek kimia dalam kalangan pelajar di Kolej MARA yang menggunakan kaedah pembelajaran berasaskan masalah melalui media sosial Facebook merentasi pendekatan pembelajaran (permukaan dan mendalam).

(Kesan utama A)

3. Mengenal pasti kesan pendekatan pembelajaran (permukaan dan mendalam) ke atas pencapaian subjek kimia dalam kalangan pelajar lelaki dan perempuan di Kolej MARA yang menggunakan kaedah pembelajaran berasaskan masalah melalui media sosial Facebook.

(Kesan utama B)

4. Mengenal pasti kesan interaksi faktor jantina dan pendekatan pembelajaran ke atas pencapaian subjek kimia dalam kalangan pelajar di Kolej MARA yang menggunakan kaedah pembelajaran berasaskan masalah melalui media sosial Facebook.

(Kesan interaksi $A x B)$

\section{HIPOTESIS KAJIAN}

Sebanyak tiga hipotesis nol telah dibentuk untuk menguji kebenaran di dalam kajian ini. Tiada hipotesis bagi objektif kajian yang pertama disebabkan analisis bagi objektif kajian tersebut dilakukan secara deskriptif. Hipotesis-hipotesis nol tersebut ialah:

$\mathrm{H}_{\mathrm{o}}$ : Tidak terdapat perbezaan yang signifikan dalam kesan faktor jantina pelajar ke atas pencapaian subjek kimia dalam kalangan pelajar di Kolej MARA yang menggunakan kaedah pembelajaran berasaskan masalah melalui media sosial Facebook merentasi pendekatan pembelajaran (permukaan dan mendalam).

$\mathrm{H}_{\circ}$ 2: Tidak terdapat perbezaan yang signifikan dalam kesan pendekatan pembelajaran (permukaan dan mendalam) ke atas pencapaian subjek kimia dalam kalangan pelajar lelaki dan perempuan di Kolej MARA yang menggunakan kaedah pembelajaran berasaskan masalah melalui media sosial Facebook.

$\mathrm{H}_{\mathrm{o}}$ 3: Tidak terdapat perbezaan yang signifikan dalam kesan interaksi faktor jantina dan pendekatan pembelajaran ke atas pencapaian subjek kimia dalam kalangan pelajar di Kolej MARA yang menggunakan kaedah pembelajaran berasaskan masalah melalui media sosial Facebook.

\section{METODOLOGI}

\section{Reka Bentuk Kajian}

Kajian ini menggunakan kaedah kuantitatif secara reka bentuk eksperimen faktorial $2 \times 2$. Kesan utama yang dikaji adalah pendekatan pembelajaran (permukaan dan mendalam) dan faktor jantina (lelaki dan perempuan). Hasil interaksi kedua-dua pemboleh ubah ini akan diukur menerusi pencapaian pelajar dalam peperiksaan akhir 
semester dua bagi subjek kimia setelah menjalani rawatan secara kaedah pembelajaran berasaskan masalah melalui media sosial Facebook.

\section{Teknik Pensampelan}

Kajian ini menggunakan kaedah pensampelan rawak berstrata. Sebelum pensampelan dibuat, penyelidik telah mendapatkan senarai nama pelajar dan juga purata nilai gred (PNG) daripada pihak Kolej MARA terbabit. Kemudian diikuti dengan pentadbiran ujian pendekatan pembelajaran pelajar untuk dikelaskan pelajar-pelajar tersebut berdasarkan jenis pendekatan pembelajaran yang diamalkan oleh mereka, sama ada pendekatan permukaan atau mendalam. Pelajar-pelajar yang telah dikelaskan berdasarkan dua ciri pendekatan pembelajaran tersebut seterusnya akan dipilih secara rawak (assign the treatment at random) untuk diberikan rawatan secara kaedah pembelajaran berasaskan masalah melalui media sosial Facebook. Ketika pemilihan secara rawak dilakukan, faktor jantina juga diambil kira agar bilangan lelaki dan perempuan tidak menunjukkan perbezaan yang terlalu ketara. Jumlah keseluruhan pelajar yang mengambil bahagian dalam kajian ini adalah seramai 120 orang pelajar dengan pelajar lelaki seramai 58 orang manakala pelajar perempuan seramai 62 orang.

\section{Pengumpulan Data}

Pengumpulan data bagi kajian ini melibatkan ujian pra (pre-test) dan ujian pos (posttest), aktiviti pembelajaran berasaskan masalah bagi sebelas kumpulan (group) Facebook pelajar dan soal selidik pendekatan pembelajaran pelajar.

\section{Ujian Pra dan Ujian Pos}

Ujian pra bagi kajian ini diambil daripada ujian pertengahan semester manakala ujian pos pula merupakan peperiksaan akhir semester pelajar. Kedua-dua ujian pra dan pos akan menguji tahap pengetahuan pelajar dalam topik dan aras kesukaran yang sama. Soalan-soalan ini disediakan oleh para pensyarah Kolej MARA dengan disemak dan dinilai semula oleh pensyarah Univesiti Kuala Lumpur (UniKL).

\section{Kumpulan Facebook Chemistry PBL pelajar}

Pelajar yang terlibat dengan kajian ini diminta untuk menyertai (join) kumpulankumpulan Facebook masing-masing sebagaimana yang telah ditetapkan oleh pensyarah. Proses pembelajaran berasaskan masalah $(P B L)$ akan berlangsung dengan pensyarah merupakan salah seorang ahli dalam setiap kumpulan tersebut. Namun peranan pensyarah hanyalah sebagai fasilitator dan memantau setiap perbincangan pelajar.

\section{Pengukuran pendekatan pembelajaran pelajar}

Bagi tujuan pengukuran pendekatan pembelajaran pelajar, instrumen yang digunakan dalam kajian ini adalah The Revised Two Factor Study Process Questionnaire (Biggs, Kember \& Leung, 2001). Instrumen ini mengandungi 20 item keseluruhannya dengan setiap pendekatan pembelajaran iaitu pendekatan permukaan dan pendekatan mendalam masing-masing mempunyai 10 item. 


\section{Prosedur Kajian}

Tempoh masa rawatan yang diberikan adalah selama satu semester (lapan belas minggu) dengan sembilan minggu pertama pelajar akan melalui pembelajaran secara bersemuka (face to face instruction) tanpa diaplikasikan media sosial dalam pembelajaran mereka. Namun, dalam tempoh tersebut para pelajar akan mula didedahkan atau diperkenalkan dengan kaedah pembelajaran berasaskan masalah. Pelajar kemudiannya akan menduduki peperiksaan pertengahan semester (mid-semester examination) pada minggu kesembilan dan kertas peperiksaan ini juga akan dijadikan sebagai ujian pra (pretest) bagi tujuan kajian ini. Minggu seterusnya iaitu minggu kesepuluh hingga minggu lapan belas (sembilan minggu), pelajar akan melalui proses pembelajaran berasaskan masalah melalui media sosial dan secara bersemuka.

Minggu Pertama Hingga Lapan

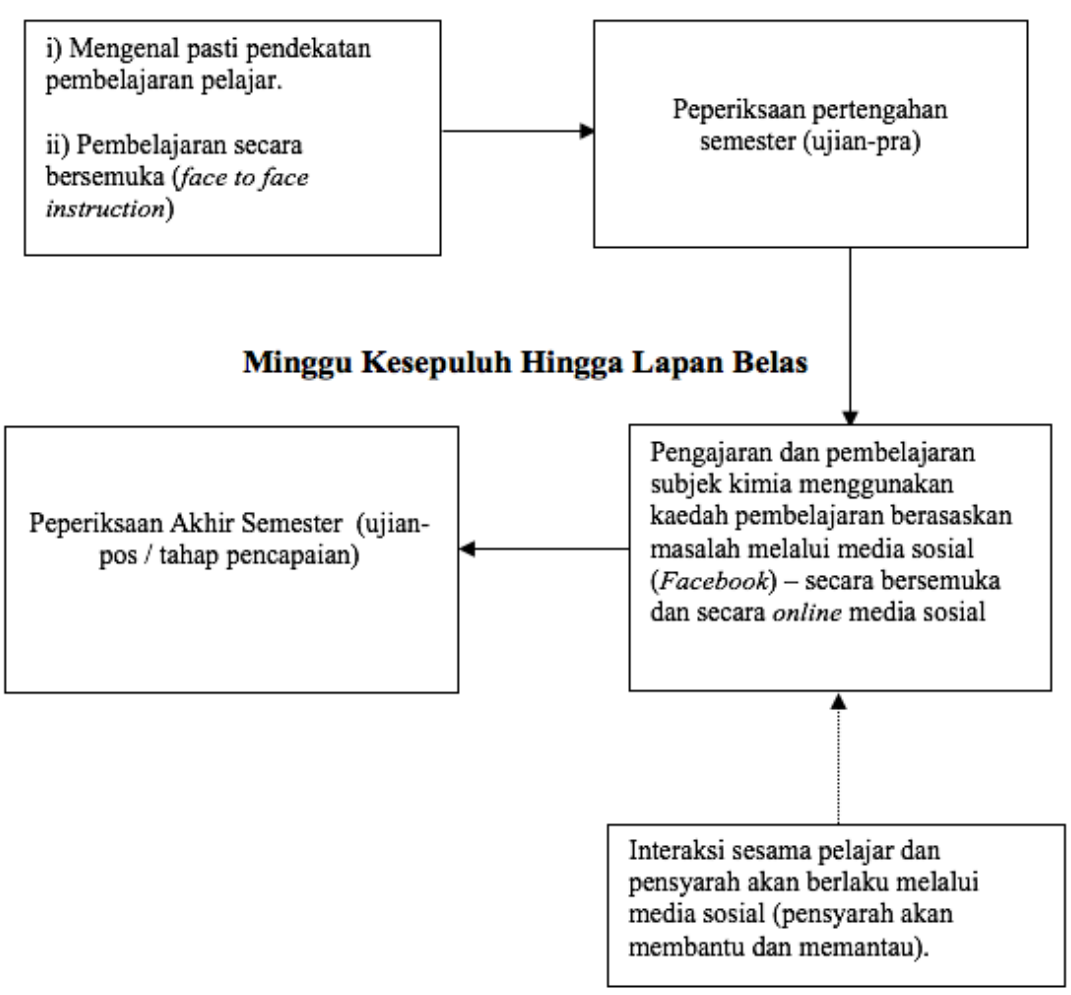

Rajah 1 Prosedur Pelaksanaan Kajian

\section{Proses Pembelajaran Chemistry PBL via Facebook}

Proses pembelajaran Chemistry PBL via Facebook adalah berdasarkan kepada Model Pembelajaran Teradun Media Sosial Berasaskan Penyelesaian Masalah yang telah diperkenalkan oleh Wiboolyasarin (2014). Berdasarkan model tersebut, terdapat lapan fasa utama yang perlu diikuti bermula dengan persediaan, mengenal pasti, menganalisis, menjalankan penyelidikan, penghasilan, pengujian, membuat rumusan dan penilaian. 
Penerangan aktiviti-aktiviti bagi setiap fasa tersebut yang disusun mengikut minggu adalah seperti berikut:

1. Persediaan (minggu pertama): Pada peringkat ini, pensyarah akan menerangkan objektif pembelajaran, aktiviti pembelajaran, proses penilaian dan cara-cara komunikasi yang dapat dilakukan menerusi media sosial Facebook. Senario permasalahan juga diberikan kepada setiap kumpulan dan aktiviti ini dilakukan secara bersemuka (face to face).

2. Mengenal pasti (minggu kedua): Pelajar diminta mengkaji situasi masalah, berbincang dan menyenaraikan sebanyak mungkin idea untuk menangani masalah. Aktiviti dilakukan secara dalam talian (online) Facebook.

3. Analisis (minggu ketiga): Perancangan untuk bekerjasama, membuat pembahagian tugas, menganalisis masalah dan merancang penyelesaian masalah. Aktiviti dilakukan secara dalam talian (online) Facebook.

4. Penyelidikan (minggu keempat dan kelima): Pelajar mengkaji, mencari, menyelidik dan mengumpul maklumat daripada pelbagai sumber. Aktiviti dilakukan secara bersemuka dan dalam talian Facebook.

5. Penghasilan (minggu keenam): Pelajar membuat hipotesis berdasarkan maklumat yang telah dikumpulkan, pengetahuan serta pengalaman sedia ada mereka. Aktiviti dilakukan secara dalam talian (online) Facebook.

6. Pengujian Hipotesis (minggu ketujuh): Para pelajar akan berbincang dan bertukar-tukar maklumat sebelum maklumat tersebut digunakan untuk pengujian hipotesis. Aktiviti dilakukan secara dalam talian (online) Facebook.

7. Rumusan (minggu kelapan): Setiap kumpulan akan membuat rumusan terhadap idea-idea, pendekatan serta analisis yang dilakukan dalam menyelesaikan sesuatu masalah. Setiap pelaporan akan dimuat naik ke dalam Facebook Chemistry $P B L$ dan ahli-ahli kumpulan yang lain akan memberikan pendapat dan komen mereka terhadap hasil kerja kumpulan yang lain pula. Aktiviti dilakukan secara bersemuka.

8. Penilaian (minggu kesembilan): Setiap kumpulan akan membentangkan hasil kajian (penyelesaian) terhadap pernyataan masalah yang diperoleh sebelum ini. Rakan-rakan pelajar daripada kumpulan lain dibenarkan untuk mengemukakan pendapat. Pensyarah juga memberikan komen dan penilaian termasuk aspek kerjasama antara ahli dalam setiap kumpulan. Aktiviti dilakukan secara bersemuka dan dalam talian Facebook. Rajah 2.0 menunjukkan carta alir bagi setiap aktiviti yang berlaku berdasarkan Model Pembelajaran Teradun Media Sosial Berasaskan Kaedah Penyelesaian Masalah.

Rajah 2 Model pembelajaran teradun media sosial berasaskan kaedah penyelesaian masalah

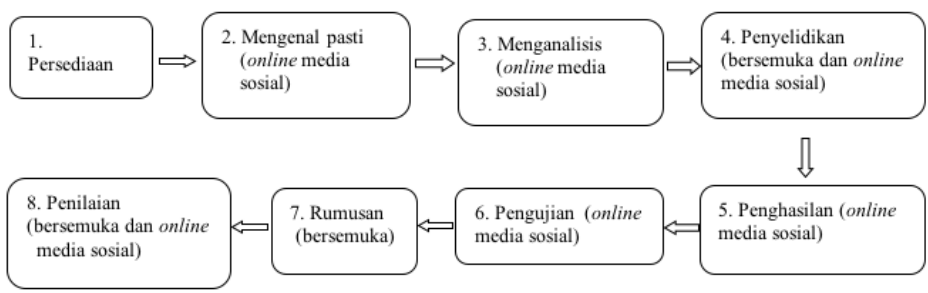




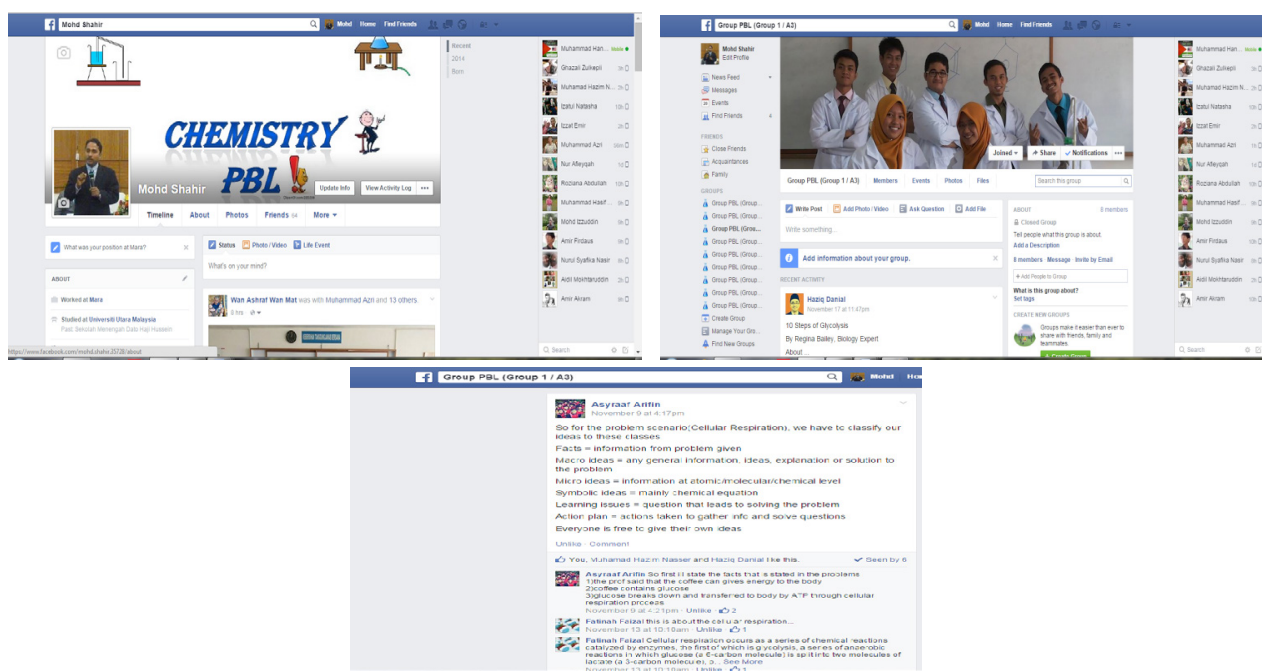

Rajah 3 Contoh Paparan Muka Hadapan Salah Satu Kumpulan PBL Berserta Perbincangan

\section{DAPATAN KAJIAN}

Kajian ini telah menggunakan analisis deskriptif bagi menjawab soalan kajian yang pertama manakala untuk soalan kajian kedua hingga keempat, statistik ujian Anova Dua-Hala telah digunakan berpandukan hipotesis-hipotesis yang telah dinyatakan sebelum ini. Namun begitu, sebelum ujian Anova Dua-Hala digunakan, penyemakan terhadap beberapa syarat yang perlu dipenuhi telah dilaksanakan seperti kenormalan (skor-skor dalam populasi bertaburan secara normal), pensampelan rawak, saiz sampel dan kesamaan varians (homogeneity of variance). Setelah didapati kesemua syaratsyarat dipenuhi, penyelidik kemudiannya meneruskan ujian statistik ke atas setiap hipotesis kajian.

\section{Pendekatan pembelajaran pelajar (permukaan dan mendalam) sebelum dan selepas menerima rawatan secara kaedah pembelajaran berasaskan masalah melalui media sosial bagi subjek kimia.}

Analisis telah dilakukan pada instrumen pendekatan pembelajaran yang diberikan kepada 120 orang pelajar sebelum dan selepas menjalani rawatan secara kaedah pembelajaran berasaskan masalah melalui Facebook. Didapati berlaku perubahan pendekatan pembelajaran pelajar selepas menjalani rawatan dengan seramai tujuh orang pelajar lelaki berubah daripada mengamalkan pendekatan pembelajaran permukaan (sebelum rawatan) kepada pendekatan pembelajaran mendalam (selepas rawatan). Keadaan yang sama juga berlaku pada pelajar perempuan di mana seramai empat orang pelajar telah berubah daripada pendekatan pembelajaran permukaan kepada pendekatan pembelajaran mendalam. Namun begitu, didapati tiada perubahan berlaku melibatkan pendekatan pembelajaran mendalam kepada pendekatan pembelajaran permukaan bagi kedua-dua jantina. Jadual 4 memperincikan pendekatan pembelajaran yang diamalkan oleh pelajar sebelum dan selepas rawatan. 
Jadual 4 Pecahan pendekatan pembelajaran pelajar berdasarkan jantina sebelum dan selepas rawatan

\begin{tabular}{lcccccc}
\hline Pendekatan & \multicolumn{2}{c}{ Sebelum PBL Facebook } & \multicolumn{4}{c}{ Selepas PBL Facebook } \\
\cline { 2 - 7 } Pembelajaran & Lelaki & Perempuan & Jumlah & Lelaki & Perempuan & Jumlah \\
\cline { 2 - 7 } Permukaan & 28 & 32 & 60 & 21 & 28 & 49 \\
Mendalam & 30 & 30 & 60 & 37 & 34 & 71 \\
\hline Jumlah & & & $\mathbf{1 2 0}$ & & & $\mathbf{1 2 0}$ \\
\hline
\end{tabular}

Analisis seterusnya adalah untuk mengkaji interaksi antara dua kesan utama pemboleh ubah tak bersandar iaitu faktor jantina dan pendekatan pembelajaran yang diamalkan oleh pelajar terhadap pemboleh ubah bersandar iaitu pencapaian dalam subjek kimia. Jadual 5 menunjukkan keputusan yang diperoleh setelah dijalankan ujian statistik Anova Dua-Hala.

Jadual 5 Analisis ANOVA mengenai Jantina dan Pendekatan Pembelajaran Pelajar

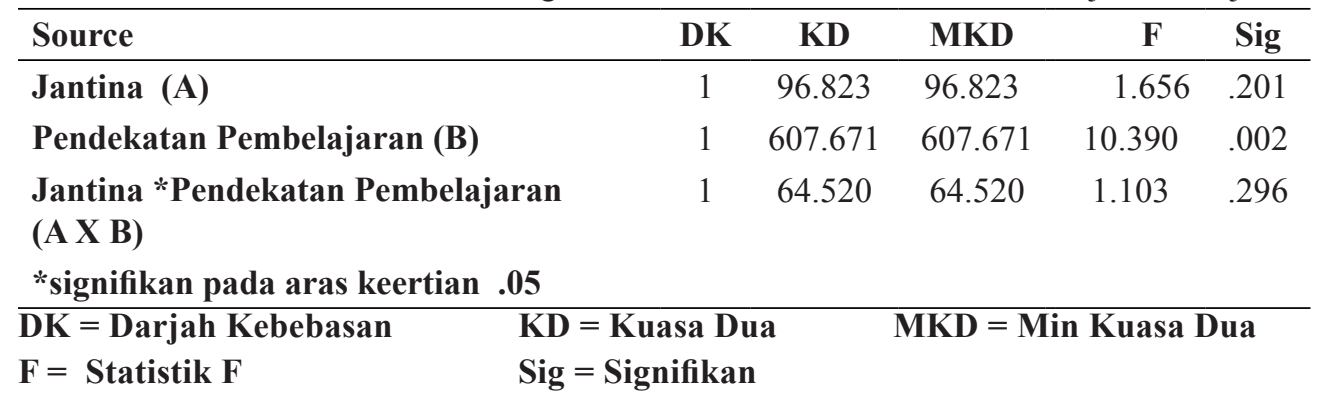

Kesan Faktor Jantina Pelajar ke atas Pencapaian Subjek Kimia dalam kalangan Pelajar di Kolej MARA yang Menggunakan Kaedah Pembelajaran Berasaskan Masalah melalui Media Sosial.

Keputusan ujian Anova Dua-Hala menunjukkan bahawa kesan utama pemboleh ubah tak bersandar jantina pelajar adalah tidak signifikan $[\mathrm{F}(1,116)=1.66$, $\mathrm{p}>$ .05] terhadap pemboleh ubah bersandar pencapaian pelajar dalam subjek kimia. Walaupun min skor pencapaian pelajar lelaki $(\min =85.5)$ lebih tinggi berbanding min skor pelajar perempuan $(\min =83.5)$, namun ianya tidak signifikan. Justeru, tiada perbezaan yang signifikan dalam pencapaian ujian pos antara pelajar lelaki dan perempuan selepas menjalani proses pembelajaran berasaskan masalah melalui media sosial. 
Jadual 6 Dapatan pencapaian ujian pos berdasarkan jantina

\begin{tabular}{ccccccc}
\hline Jantina & N & min & sp & dk1 & F & p \\
\hline Lelaki & 58 & 85.5 & 8.44 & 1 & 1.66 & .20 \\
Perempuan & 62 & 83.5 & 7.45 & 1 & & \\
\hline & 120 & & & & \\
\hline
\end{tabular}

$* \mathbf{p}<.05$

Kesan Pendekatan Pembelajaran Pelajar ke atas Pencapaian Subjek Kimia dalam kalangan Pelajar di Kolej MARA yang Menggunakan Kaedah Pembelajaran Berasaskan Masalah melalui Media Sosial.

Keputusan ujian Anova Dua-Hala menunjukkan bahawa kesan utama pemboleh ubah tak bersandar pendekatan pembelajaran pelajar adalah signifikan $[\mathrm{F}(1,116)=10.39$, $\mathrm{p}<.05$ ] terhadap pemboleh ubah bersandar pencapaian pelajar dalam subjek kimia. Didapati nilai min pendekatan pembelajaran mendalam $(\min =86.7)$ mengatasi nilai min pendekatan permukaan $(\min =82.2)$. Keadaan ini menunjukkan bahawa secara signifikan, pelajar yang mengamalkan pendekatan pembelajaran mendalam ketika mengikuti proses pembelajaran berasaskan masalah melalui media sosial Facebook memperoleh skor pencapaian yang lebih tertinggi berbanding kumpulan pelajar yang mengamalkan pendekatan permukaan.

Jadual 7 Dapatan pencapaian ujian pos berdasarkan pendekatan pembelajaran

\begin{tabular}{ccccccc}
\hline $\begin{array}{c}\text { Pendekatan } \\
\text { Pembelajaran }\end{array}$ & N & min & sp & dk1 & F & p \\
\hline Permukaan & 60 & 82.2 & 8.68 & 1 & 10.39 & $.00^{*}$ \\
Mendalam & 60 & 86.7 & 6.51 & 1 & & \\
\hline & 120 & & & & &
\end{tabular}

$* \mathbf{p}<.05$

Kesan Interaksi Faktor Jantina dan Pendekatan Pembelajaran ke atas Pencapaian Subjek Kimia dalam kalangan Pelajar di Kolej MARA yang Menggunakan Kaedah Pembelajaran Berasaskan Masalah melalui Media Sosial.

Kesan interaksi antara kedua-dua pemboleh ubah bebas (Jantina*Pendekatan Pembelajaran) terhadap pemboleh ubah bersandar (pencapaian pelajar) melalui kaedah pembelajaran berasaskan masalah melalui media sosial Facebook didapati wujud secara tidak signifikan $[\mathrm{F}(1,116)=1.10, \mathrm{p}>.05]$. Keadaan ini bermakna interaksi kedua-dua pemboleh ubah bebas (jantina dan pendekatan pembelajaran) tidak memberi sebarang kesan yang signifikan terhadap pencapaian pelajar dalam subjek kimia secara pembelajaran berasaskan masalah melalui media sosial. Walaupun min skor pencapaian pelajar lelaki yang mengamalkan pendekatan mendalam $(\min =88.4)$ lebih tinggi berbanding min skor pelajar perempuan yang mengamalkan pendekatan 
mendalam $(\min =85.1)$, namun ianya tidak signifikan. Selain itu, min pencapaian pelajar lelaki yang mengamalkan pendekatan permukaan $(\min =82.4)$ didapati tidak menunjukkan perbezaan yang ketara dengan pelajar perempuan yang mengamalkan pendekatan permukaan $(\min =82.1)$.

Jadual 8 Dapatan pencapaian ujian pos berdasarkan jantina dan pendekatan pembelajaran

\begin{tabular}{ccccccc}
\hline Jantina & $\begin{array}{c}\text { Pendekatan } \\
\text { Pembelajaran }\end{array}$ & min & sp & dk1 & F & p \\
\hline \multirow{2}{*}{ Lelaki } & Mendalam & 88.4 & 5.71 & 1 & 1.10 & .29 \\
& Permukaan & 82.4 & 9.81 & 1 & & \\
\multirow{2}{*}{ Perempuan } & Mendalam & 85.1 & 6.95 & 1 & & \\
& Permukaan & 82.1 & 7.71 & 1 & & \\
& & & & & &
\end{tabular}

\section{PERBINCANGAN}

Dapatan kajian ini menunjukkan bahawa kaedah pembelajaran berasaskan masalah $(P B L)$ melalui media sosial Facebook telah berjaya menggalakkan pelajar untuk mengamalkan pendekatan pembelajaran mendalam berbanding pendekatan pembelajaran permukaan. Hal ini dapat dilihat daripada analisis deskriptif kajian yang menunjukkan berlakunya peralihan daripada amalan pendekatan pembelajaran permukaan kepada pendekatan pembelajaran mendalam membabitkan tujuh orang pelajar lelaki dan empat orang pelajar perempuan selepas menjalani kaedah pembelajaran tersebut. Perubahan daripada pendekatan pembelajaran permukaan kepada pendekatan pembelajaran mendalam merupakan salah satu kejayaan dalam proses pembelajaran selain daripada memperoleh markah yang tinggi dalam sesuatu penilaian atau peperiksaan akhir (Biggs, 2003). Hal ini disebabkan pelajar yang mengamalkan pendekatan pembelajaran permukaan akan bergantung pada hafalan fakta semata-mata tanpa berusaha memahami pelajaran yang dipelajari. Sebaliknya, pelajar yang berusaha dengan bersungguh-sungguh untuk memahami secara lebih mendalam bagi sesuatu pelajaran (mengamalkan pendekatan mendalam) kebiasaannya menunjukkan pencapaian yang lebih baik dalam peperiksaan (Biggs \& Moore, 1993). Dapatan kajian ini didapati selari dengan beberapa kajian terdahulu (seperti Stiernborg \& Bandaranayake, 1996; Samarakoon, Fernando, dan Rodrigo, 2013) yang turut menggunakan kaedah pembelajaran berasaskan masalah ( $P B L)$ sebagai kaedah pengajaran.

Namun, perbezaan kaedah pembelajaran berasaskan masalah bagi kajian ini adalah dari segi integrasi media sosial Facebook yang didapati masih kurang dikaji secara meluas buat masa ini. Kajian ini mendapati perubahan daripada pendekatan pembelajaran permukaan kepada pendekatan pembelajaran mendalam melibatkan 9\% daripada jumlah keseluruhan pelajar selepas mereka menjalani kaedah pembelajaran berasaskan masalah $(P B L)$ melalui media sosial selama 9 minggu. Justeru, perubahan 
yang berlaku secara puratanya adalah $1 \%$ atau seorang pelajar bagi setiap minggu. Perubahan yang berlaku ini sangat memberangsangkan walau pun pelajar didapati masih dalam proses pengenalan dan penyesuaian terhadap kaedah $P B L$ yang dianggap masih baharu bagi mereka. Hasil kajian ini juga menunjukkan bahawa kaedah pembelajaran teradun (blended learning) melalui media sosial seperti Facebook dapat meningkatkan pencapaian akademik pelajar. Dapatan ini adalah selari dengan kajian-kajian lepas seperti yang dijalankan oleh Köse (2010) serta Archambault, Wetzel, Foulger dan Williams (2010) yang telah merumuskan bahawa pencapaian akademik pelajar dapat ditingkatkan sekiranya pembelajaran teradun melalui media sosial diaplikasikan dalam proses pembelajaran mereka. Namun begitu, hasil dapatan kajian oleh Köse (2010) didapati bergantung sepenuhnya kepada persepsi pelajar dalam mentaksirkan tahap pencapaian mereka manakala kajian oleh Archambault et al. (2010) pula telah menggunakan persepsi daripada para guru dalam mentaksirkan pencapaian akademik pelajar. Berbeza dengan kajian ini, pencapaian pelajar adalah berdasarkan markah sebenar pelajar dalam peperiksaan akhir subjek yang dikaji iaitu subjek kimia.

Dapatan ujian Anova Dua-Hala dengan pemboleh ubah tak bersandar (pendekatan pembelajaran dan faktor jantina) terhadap pemboleh ubah bersandar (pencapaian pelajar) didapati memberikan keputusan yang berbeza-beza. Data kajian menunjukkan bagi kesan utama pemboleh ubah pendekatan pembelajaran pelajar, nilai min pendekatan pembelajaran mendalam $(\mathrm{min}=86.7)$ mengatasi nilai min pendekatan pembelajaran permukaan $(\min =82.2)$. Hal ini menunjukkan bahawa secara signifikan, pelajar yang mengamalkan pendekatan pembelajaran mendalam berjaya memperoleh pencapaian yang lebih tinggi berbanding pelajar yang mengamalkan pendekatan pembelajaran permukaan selepas menjalani kaedah pembelajaran berasaskan masalah melalui media sosial Facebook. Dapatan kajian ini didapati selari dengan beberapa kajian sebelum ini (Entwistle \& Ramsden, 1983; Abdul Rahim, 2004; Gomes, 2011; Liu, Ye \& Yeung, 2014; dan Armstrong, 2014) yang mendapati pelajar yang mengamalkan pendekatan pembelajaran mendalam akan memperoleh pencapaian yang lebih baik berbanding pelajar yang mengamalkan pendekatan pembelajaran permukaan. Namun begitu, terdapat beberapa faktor lain yang boleh mempengaruhi pemilihan pendekatan pembelajaran dalam kalangan pelajar. Sebagai contoh, Abdul Rahim (2004) mendapati faktor usia mempengaruhi pemilihan pendekatan pembelajaran dengan pelajar yang lebih berusia cenderung untuk mengamalkan pendekatan pembelajaran mendalam berbanding pelajar yang lebih muda. Justeru, pelajar yang lebih berusia akan memperoleh pencapaian yang lebih baik di samping memahami sesuatu pelajaran dengan lebih terperinci (Abdul Rahim, 2004). Begitu juga dengan kajian Gomes (2011) yang mendapati terdapat perbezaan dari segi pola pemilihan pendekatan pembelajaran berdasarkan tahun pengajian di mana pelajar dengan tahun pengajian yang lebih tinggi cenderung untuk memilih pendekatan pembelajaran mendalam. Dapatan kajian Armstrong (2014) pula mendapati faktor strategi pengajaran boleh mempengaruhi pemilihan pendekatan pembelajaran dalam kalangan pelajar dan seterusnya menentukan pencapaian akademik pelajar dalam subjek tertentu. Bagi kajian ini, faktor usia tidak mempengaruhi dapatan kajian disebabkan kesemua pelajar adalah sebaya selain hanya 
seorang pensyarah sahaja yang telah ditugaskan untuk mengajar. Justeru, perubahan pendekatan pembelajaran yang berlaku dalam kalangan pelajar yang terlibat dengan kajian ini adalah disebabkan faktor strategi pengajaran yang digunakan (Armstrong, 2014) iaitu secara kaedah pembelajaran berasaskan masalah melalui media sosial Facebook.

Namun begitu, kesan utama bagi jantina pelajar didapati tidak signifikan terhadap pencapaian dalam subjek kimia. Begitu juga dengan kesan interaksi antara kedua-dua pemboleh ubah tak bersandar (pendekatan pembelajaran * jantina) yang juga didapati wujud secara tidak signifikan. Justeru, kaedah pembelajaran berasaskan masalah $(P B L)$ melalui media sosial didapati tidak menunjukkan perbezaan yang ketara dari segi pencapaian dalam subjek kimia dalam kalangan pelajar lelaki atau perempuan. Kesimpulannya, hasil kajian ini menunjukkan kaedah pembelajaran berasaskan masalah melalui media sosial sesuai digunakan dalam kalangan pelajar yang mengamalkan pendekatan pembelajaran yang berbeza-beza dan seterusnya berpotensi dalam mendorong pelajar yang mengamalkan pendekatan pembelajaran permukaan berubah kepada pendekatan pembelajaran mendalam. Hasil amalan pendekatan pembelajaran mendalam dalam kalangan pelajar ini seterusnya akan membolehkan pelajar tersebut memperoleh pencapaian yang cemerlang dalam akademik.

\section{KESIMPULAN}

Kaedah pembelajaran berasaskan masalah $(P B L)$ melalui media sosial Facebook didapati berpotensi dalam menggalakkan berlakunya peralihan pendekatan pembelajaran pelajar daripada pendekatan pembelajaran permukaan kepada pendekatan pembelajaran mendalam. Sebagaimana yang telah dinyatakan sebelum ini, pendekatan pembelajaran mendalam dilihat sebagai satu pendekatan pembelajaran yang diingini kerana memberi kesan yang baik terhadap kualiti pencapaian akademik pelajar untuk jangka masa yang panjang. Pernyataan tersebut disokong pula dengan dapatan kuantitatif kajian ini yang mendapati pencapaian dalam subjek kimia bagi pelajar yang mengamalkan pendekatan pembelajaran mendalam didapati lebih tinggi dan berbeza secara signifikan berbanding pelajar yang mengamalkan pendekatan pembelajaran secara permukaan merentasi jantina pelajar. Selain itu, kaedah pembelajaran berasaskan masalah melalui media sosial juga sesuai digunakan dalam pembelajaran subjek kimia di peringkat yang lebih awal (contohnya di peringkat persediaan universiti) kerana pendedahan awal kepada kaedah tersebut membolehkan pelajar mengetahui bagaimana untuk mengaplikasi pengetahuan yang dipelajari dalam situasi kehidupan sebenar. 
KESAN INTERAKSI PENDEKATAN PEMBELAJARAN DAN FAKTOR JANTINA PELAJAR KE ATAS PENCAPAIAN SUBJEK KIMIA MELALUI KAEDAH PBL via FACEBOOK

\section{RUJUKAN}

Abdul Rahim Hamdan. (2004). Student Study Approach Preferences and Motivation in Teacher Training in Malaysia. Tesis PhD. University of Surrey, United Kingdom.

Aghili, M., Palaniappan, A. K., Kamali, K., Aghabozorgi, S., \& Sardareh, S. A. (2014). Unifying informal and formal learning environments: Educational use of social network sites through implementing community of inquiry framework. International Journal of e-Education, e-Business, e-Management and e-Learning, 4(3), 191-196.

Alexander, B. (2006). Web 2.0: A new wave of innovation for teaching and learning? EDUCAUSE Review, 41(2), 32-44.

Archambault, L., Wetzel, K., Foulger, T. S., \& Williams, M. K. (2010). Profesional development 2.0: Transforming teacher education pedagogy with 21st century tools. Journal of Digital Learning in Teacher Education, 27(1), 4-11.

Armstrong, P. G. (2014). The effects of students' approach to learning and instructional strategy (delivery) on academic success. Tesis $\mathrm{PhD}$. Capella University.

Bandura, A. (1977). Social learning theory. Englewood Cliffs, New Jersey: PrenticeHall.

Barrows, H. S., \& Tamblyn, R. M. (1980). Problem-Based Learning: An Approach to Medical Education. New York: Springer Publishing Company.

Barrows, H. S., \& Kelson, A. (1993). Problem-based learning in secondary education and the problem-based learning institute. Southern Illinois University School of Medicine. Springfield, IL.

Biggs, J. B. (1987). Student Approaches To Learning And Studying. Hawthorn, Victoria: Australian Council for Educational Research.

Biggs, J. B., \& Moore, P. J. (1993). The process of learning (3rd ed.). NewYork: Prentice Hall.

Biggs, J., Kember, D., \& Leung, D. Y. P. (2001). The revised two-factor study process questionnaire: R-SPQ-2F. British Journal of Educational Psychology, 71, 133149.

Biggs, J. B. (2003). Teaching for Quality Learning at University (2 ${ }^{\text {nd }}$ ed.). Buckingham: The Society for Research into Higher Education \& Open University Press.

Birch, D. \& Volkov, M. (2007). Assessment of online reflections: Engaging English second language (ESL) students. Australian Journal of Educational Technology, 23(3), 291- 306.

Boyd, D., \& Ellison, N. (2008). Social network sites: Definition, history \& scholarship, Journal of Computer-Mediated Communication, 13, 210-230.

Çevik, Y. D. (2014). Teacher training through social networking platforms : A case study on Facebook. Computers in Human Behavior, 30(6), 714-727.

Duff, A., Boyle, E., Dunleavy, K., \& Ferguson, J. (2004). The relationship between personality, approach to learning and academic performance. Personality and Individual Differences, 36, 1907-1920. 
Entwistle, N. J., \& Ramsden, P. (1983). Understanding student learning. London: Croom Helm.

Entwistle, N. (1997). Reconstituting approaches to learning: A response to Webb. Higher Education, 33(2), 213-218.

Facebook.com. (2012). One billion people on Facebook. http://newsroom.fb.com/ News/457/One-Billion-People-on- Facebook. Dicapai pada 15Disember 2012.

Facebook.com. (2017). Facebook Reports First Quarter 2017 Results. $\underline{\text { h t t p : / / }}$ investor.fb.com/releasedetail.cfm?ReleaseID=780093 Dicapai pada 3 Mac 2017.

Faaizah, S., \& Halimah, B. Z. (2007). C2HADAM: Hybrid PBL multimedia and web based courseware for science. Kertas yang dibentangkan dalam Seminar Antarabangsa Sains dan Matematik (CoSMEd), pada 13-16 November 2007, di SEAMEO RECSAM, Pulau Pinang, Malaysia.

Gomes, C. M. A. (2011). Deep and surface approach to learning: Different perspectives about academic achievement. Psicologia: Reflexao e Critica, 24(3), 86-93.

Hartshorne, R., \& Ajjan, H. (2009). Examining student decision to adopt Web 2.0 technologies: theory and empirical tests. Journal of Computing in Higher Education, 21(3), 183-198.

Hein, J. O. (2014). A Comparison of a Blended Learning Environment and a Traditional Learning Environment. Are Student Achievement and Student Interest Affected? Tesis Doktor Falsafah Pendidikan. Universiti Wilmington.

Hung, D. (2002). Bringing communities of practice into schools: Implications for instructional technologies from Vygotskian perspectives. International Journal of Instructional Media, 29(2), 171-183.

Hussain Othman, \& Berhannudin M. Salleh. (2009). First Year Students First Year $P B L$ Experience in a Large Class. Kertas yang dibentangkan dalam Simposium Antarabangsa PBL 2009, pada 10-12 Jun 2009, di Republic Polytechnic, Singapura.

Kabilan, M. K., Ahmad, N., \& Zainol Abidin, M. J. (2010). Facebook: An online environment for learning of English in institutions of higher education? Internet and Higher Education, 13(4), 179-187.

Karpinski, A. (2010). Facebook and academic performance. Computer in Human Behavior, 26(6), 1237-1245.

Kearsley, G. (2011). The Theory Into Practice Database. http://tip.psychology.org Dicapai pada 3 Januari 2013.

Khairiyah Mohd Yusof, Syed Ahmad Helmi Syed Hassan, \& Zaidatun Tasir (2009). Inducting First Year Engineering Students into Problem-Based Learning. Kertas yang dibentangkan dalam Simposium Antarabangsa PBL, pada 10-12 Jun 2009, di Republic Polytechnic, Singapure.

Köse, U. (2010). A blended learning model supported with Web 2.0 technologies. Procedia Social and Behavioral Sciences, 2(2), 2794-2802.

Liu, E. S. C., Ye, C. J., \& Yeung, D. Y. (2014). Effects of approach to learning and self-perceived overall competence on academic performance of university students. Learning and Individual Differences, 39, 199-204. Elsevier Ltd.

Manca, S., \& Ranieri, M. (2013). Is it a tool suitable for learning? A critical review of the literature on Facebook as a technology-enhanced learning environment. Journal of Computer Assisted Learning, 29(6), 487-504. 
Mao, J. (2014). Social media for learning: A mixed methods study on high school students' technology affordances and perspectives. Computers in Human Behavior, 33, 213-223. doi:10.1016/j.chb.2014.01.002

Mazman, S. G., \& Usluel, Y. K. (2010). Modeling educational usage of Facebook, Computer \& Education, 55, 444-453.

Newble, D., \& Hejka, E. J. (1991). Approaches to learning of medical students and practising physicians: some empirical evidence and its implications for medical educations. Educational Psychology, 11(3-4), 333-342.

Paul, I. (2010). Facebook's half billion users: Fun facts. http://www.pcworld. comarticle/201650/facebooks half_billion_users_Dicapai pada 25 Jun 2011.

Price, K. (2006). Web 2.0 and education: What it means for us all. Kertas yang dibentangkan dalam Australian Computers in Education Conference, pada 2-4 Oktober 2006, di Cairns, Australia.

Rainie, L. (2009). Back to the future. Pew Research Center's Internet and American Life Project.http://pewinternet.org/Presentations2009/49-NCTI-TechnologyInnovators- Conference.aspx Dicapai pada 28 Mac 2011

Ramsden, P. (1992). Learning to teach in higher education. London: Routledge.

Roblyer, M. D., McDaniel, M., Webb, M., Herman, J., \& Witty, J. V. (2010). Findings on facebook in higher education: A comparison of college faculty and student uses and perceptions of social networking sites. The Internet and Higher Education, 13(3), 134-140.

Samarakoon, L., Fernando, T., \& Rodrigo, C. (2013). Learning styles and approaches to learning among medical undergraduates and postgraduates. BMC Medical Education, 13(1), 42.

Shih, R. C. (2011). Can Web 2.0 technology assist college students in learning English writing? Integrating facebook and peer assessment with blended learning, Australasian Journal of Educational Technology, 27(5), 829-845.

Shittu, A. T., Basha, K. M., Abdul Rahman, N. S. N., \& Ahmad, T. B. T. (2011). Investigating students' attitude and intention to use social software in higher institution of learning in Malaysia, Multicultural Education \& Technology Journal, 5(3), 194-208.

Sobaih, A. E. E., Moustafa, M. A., Ghandforoush, P., \& Khan, M. (2016). To use or not to use? Social media in higher education in developing countries. Computers in Human Behavior, 58, 296-305. Elsevier Ltd.

Socialbakers.com. (2015). Malaysia Facebook statistics. http://www.socialbakers. com/facebook-statistics/malaysia. Dicapai pada 2 April 2015.

Stiernborg, M., \& Bandaranayake, R. C. (1996). Medical students' approaches to studying. Medical Teacher, 18(3), 229-236.

Syed Shah Alam, Yeow, P. H. P., \& Loo, H. S. (2011). An empirical study on online social networks sites usage: Online dating sites perspective, International Journal of Business and Management, 6(10), 155.

Tan, Y. P., \& Mohammad Yusof Arshad. (2014). Teacher and student questions: A case study in Malaysian secondary school problem-based learning. Asian Social Science, 10(4), 174-182. 
Tess, P. A (2013). The role of social media in higher education classes (real and virtual) - a literature review. Journal of Computers in Human Behavior, 29, 60-68.

Treepuech, W. (2011). The application of using social networking sites with available online tools for teaching and learning management. Kertas yang dibentangkan dalam IT in Medicine and Education (ITME) 2011, di International Symposium, Sapporo, Japan, pada 5-7 Ogos 2011.

Watkins, D. (1982). Identifying the study process dimensions of Australian university students. The Australian Journal of Education, 26(1), 76-84.

Wiboolyasarin, W. (2014). Blended problem-based instructional model via Facebook application on mobile: Are you ready for m-Learning?. International Journal of e- Education, e-Business, e-Management and e-Learning, 4(2), 91-94.

Vygotsky, L. S. (1978). Mind in Society: The Development of Higher Psychological Processes. Cambridge, Massachusetts: Harvard University Press. 